16,9\% số trường hợp và chủ yếu ở độ 1,2 . Xuất hiện tăng lên ở những chu kỳ sau và có $1,7 \%$ độ 3-4, phải giảm liều thuốc Capecitabine $25 \%$.

Tác dụng không mong muốn trên thần kinh ngoại vi là biểu hiện thường gặp liên quan tới liều điều trị Oxaliplatin. Bao gồm độc tính cấp xuất hiện ngay trong hoặc sau quá trình truyền thuốc. Tính chung cả 6 chu kỳ hóa chất gặp $30,1 \%$ các trường hợp và thường tăng lên ở những chu kỳ cuối. Chủ yếu ở mức độ 1,2 với dấu hiệu dị cảm nhẹ, tê đâu chi, không ảnh hưởng đến điều trị

Có 05 bệnh nhân dung nạp thuốc kém phải chuyển sang phác đồ xelox do dung nạp thuốc kém.

\section{KẾT LUÂN}

Tác dụng không mong muốn chung trên huyết học chủ yếu ở độ 1 , trong đó có $1,5 \%$ hạ bạch cầu, 2,6\% hạ bạch câu hạt độ 3 - 4 và $0,4 \%$ hạ tiểu cầu độ 4

Tác dụng không mong muốn chung trên chức năng gan thận chủ yếu ở độ $1-2$, trong đó cao nhất là tăng SGOT $(29,3 \%)$ và SGPT $(20,2 \%)$

Tác dụng không mong muốn chung trên lâm sàng chủ yếu ở độ 1 , trong đó có có $3,2 \%$ số đợt nôn mức độ 3- 4, 1,5\% tiêu chảy mức độ 3-
4. Bệnh nhân chán ăn mức độ 3-4 gặp 2,6\% .

Có 05 bệnh nhân dung nạp kém phải chuyển phác đồ Xelox do dung nạp thuốc kém

\section{TÀI LIẸU THAM KHẢO}

1. World Health Organization (2018). Gastric Cancer. International Agency for Research on Cancer, GLOBOCAN 2018.

2. Vũ Hải (2009), Nghiên cứu chỉ định các phương pháp phâu thuật, hoá chất bố trợ và đánh giá kết quả điêu trị ung thư dạ dày tại Bệnh viện K, Luận án Tiến sĩ y học, Hoc viện Quần y.

3. Phan Cảnh Duy (2019), "Kết quả điều trị ung thư biểu mô tuyến dạ dây phần xa da dày giai đoan tiến triển tai chố bằng phẫu thuât kết hợp xa - hóa sau mổ", Tạp chí Y học lâm sàng, Bệnh viện Trung Ương Huể, số 55 , tr. $80-88$.

4. Đố Trọng Quyết (2010), Nghiên cứu điều trị ung thư dạ dày bằng phẫu thuật có kết hợp ELF và miển dịch trị liệu ASLEM, Luận án Tiến sĩ y học, Đai học Y Hà Nối.

5. Vữ Quang Toản, Đoàn Hữu Nghi, Đỗ Anh Tú (2015) , "Điều trị ung thư da dày tiển triển tại chổ bằng phẫu thuật và hóa trị bổ trợ EOX", Tạp chí Y học lâm sàng, số 29/2015, trt.270-278.

6. Đă̆ng Hoàng An, Nguyê̂n Thanh Ái, Pham Như Hiệp và cs (2015). "Đánh giá kết quả điêu trị bổ trợ ung thư da dày giai đoạn II-III bằng xạ trị và hóa trị với phác đồ EOX tại Bênh viên Trung ương Huế". Tạp chí y học lâm sàng, số 29, tr.258-269.

\title{
NGHIÊN CỨU YẾU TỐ TIÊN LƯỢ'NG TỬ VONG Ở BỆNH NHÂN NGộ ĐộC CẤP METHANOL
}

\section{TÓM TẮT}

Mục tiêu: Đánh giá các yễu tố lâm sàng, cận lâm sàng và điều trị liên quan đến tử vong ở bệnh nhân ngộ độc cấp methanol. Đối tượng và phương pháp: Nghiên cứu mô tả trên 107 bệnh nhân ngộ độc cấp methanol điêu trị tại Trung tâm chống độc bệnh viện Bạch Mai từ 01/2016 đến 07/2019. Kết quả: Bệnh nhân chủ yếu là nam giới $(97,2 \%)$; tuổi trung bình là 47,6 $\pm 12,6$ năm và nhóm tuối 40-59 găp nhiều nhất $(65,4 \%)$. Ngộ độc methanol thường nặng, tỉ lệ tử vong cao $(41,1 \%)$. Một số yếu tố liên quan đến tử vong ở bệnh nhân ngộ độc cấp methanol: đến viện muộn sau ngộ độc quá 24 giờ (OR 1,$04 ; p<0,05)$; hổn mê sâu (OR 0,24; $p<0,05)$; toan chuyển hóa nặng pH $<7,0$ (OR 0,22; $p<0,05$; Suy thận cấp (OR 5,13;

\footnotetext{
${ }^{1}$ Trung Tâm Chống Độc - Bệnh viện Bạch Mai

${ }^{2}$ Trường Đại học Y Hà Nội

Chịu trách nhiệm chính: Đặng Thị Xuân

Email: xuandangthi@bachmai.edu.vn

Ngày nhận bài: 01.3.2021

Ngày phản biện khoa học: 27.4.2021

Ngày duyệt bài: 10.5.2021
}

\section{Đặng Thị Xuân ${ }^{1}$, Hà Trần Hưng ${ }^{1,2}$}

$p<0,05)$; tăng glucose máu (OR 13,28; $p<0,05$ ); tụt huyết áp phải dùng thuốc vận mạch (OR 0,019; $\mathrm{p}<0,01)$. Kết luận: Nghiên cứu cho thấy sự liên quan giữa một số đặc điểm về lâm sàng, cận lâm sàng và điều trị với tử vong ở bệnh nhân ngộ độc cấp methanol. lượng.

Tư khóa: ngộ độc methanol, tử vong, yếu tố tiên

\section{SUMMARY \\ RESEARCH OF FACTORS RELATED TO MORTALITY IN PATIENTS WITH METHANOL POISONING}

Objective: to evaluate the factors related to fatal outcome in the patients with acute methanol poisoning. Subjects and Methods: A analysis observational study included 107 patients with methanol intoxication treated at Poison Control Center of Bach Mai Hospital from January 2016 to July 2019. Results: The study patients were mainly male $(97.2 \%)$, the mean age were $47.6 \pm 12.6$ years and mainly in the age group of 40-59 (65.4\%). Methanol poisoning is severe with high mortality rate $(41.1 \%)$. Some main factors related to death in patients with acute methanol poisoning: delay admission (more 
than 24 hours from ingestion to hoospital admission) (OR 1.04; $\mathrm{p}<0.05$ ); deep coma on admission (OR $0.24 ; \mathrm{p}<0.05)$; severe metabolic acidosis $\mathrm{pH}<7.0$ (OR 0.22 ; $\mathrm{p}<0.05$; acute renal failure (OR 5.13 ; $\mathrm{p}$ $<0.05$ ); hyperglycemia (OR 13.28; $p<0,05$ ); Hypotension requires vasopressors (OR 0.019; $p$ <0.01). Conlusion: The study showed the association between some clinical, laboratory and therapeutic predictors with mortality in patients with acute methanol poisoning.

Keywords: methanol poisoning, mortality, predictors.

\section{I. ĐĂT VẤN ĐỀ}

Ngộ độc cấp methanol là cấp cứu khá thường gặp. Methanol là loại cồn được sử dụng nhiều trong công nghiệp, là thành phần dùng để tổng hợp nhiều chất hữu cơ và là dung môi của số lượng lớn các sản phẩm thương mại trên thị trường. Methanol có độc tính cao, không được dùng làm rượu thực phẩm. Ngộ độc methanol gặp ở nhiều nơi trên thế giới, như các vụ ngộ độc ở Campuchia, Cộng hòa Séc, Iran, Ân Độ... với tỷ lệ tử vong có nơi lên tới $48 \%$... Ở việt Nam, nhiêu người hay uống rượu tự pha chế, rượu không rõ nguồn gốc, ý thức chủ quan của người tiêu dùng, do quản lý chưa tốt nên ngộ độc methanol ngày càng tăng. Theo Bộ $Y$ tể hàng năm có khoảng trên 1000 ca ngộ độc methanol và trên 20 người tử vong. Tại Trung tâm chống độc Bệnh viện Bạch Mai năm 2017 có 51 bệnh nhân (BN), 6 tháng đầu năm 2019 có 16 BN. Theo nghiên cứu của Phạm Như Quỳnh từ 2016 đến 2017 có 37 BN ngộ độc methanol, tỉ lệ tử vong lên đến $35,2 \%$ và di chứng là $37,8 \%$ [1]. Mặc dù hiện nay có các biện pháp điều trị như lọc máu, dùng thuốc giải độc đặc hiệu nhưng tỷ lệ tử vong còn rất cao. Xác định yếu tố tiên lượng tử vong có vai trò quan trọng trong điêu trị sớm, giảm di chúng và tử vong của bệnh nhân. Trên thế giới cũng có một số nghiên cứu về các yếu tố tiên lượng tử vong bệnh nhân ngộ độc methanol. Ở Việt Nam còn thiếu nghiên cứu về tiên lượng và liên quan tới tử vong của ngộ độc cấp methanol, do vậy chúng tôi tiến hành nghiên cứu này nhằm mục tiêu "Đánh giá các yếu tố liên quan đến tử vong ở bệnh nhân ngộ độc câp methanol" ở bệnh nhân ngộ độc cấp methanol tại Trung tâm chống độc bệnh viện Bạch Mai.

\section{II. ĐỐI TƯợNG VÀ PHƯƠNG PHÁP NGHIÊN CỨU}

2.1. Đối tượng nghiên cứu: Bệnh nhân ngộ độc cấp methanol điều trị tại Trung tâm Chống độc bệnh viện Bạch Mai từ tháng 1/2016 đến $7 / 2019$.

\section{Tiêu chuẩn chon bênh nhân}

- Bệnh sử có uống rượu hoặc hóa chất nghi ngờ có methanol.

- Định lượng có methanol trong máu.

\section{Tiêu chuẩn loai trừ}

- Ngộ độc phổi hợp với chất khác (ngoài ethanol): thuốc ngủ, hóa chất bảo vệ thực vật...

- Tiên sử bệnh có di chứng thần kinh trung ương và di chứng thần kinh thị giác từ trước

\subsection{Phương pháp nghiên cứu}

Thiết kế nghiên cứu: Nghiên cứu mộ tả

Phương pháp chọn mâuu: chọn mẫu toàn bộ. Mẫu nghiên cứu gồm 107 bệnh nhân, chia làm 2 nhóm: nhóm bệnh nhân sống $63 \mathrm{BN}$, nhóm bệnh nhân tử vong $44 \mathrm{BN}$

Nội dung và tiến hành nghiên cứu: bệnh nhân đủ tiêu chuẩn lựa chọn được tiến hành thu thập số liệu theo mẫu bệnh án thống nhất:

- Các thông tin hành chính: Họ tên, tuổi, giới, địa chỉ, nghề nghiệp

- Tiên sử bệnh, nguyên nhân ngộ độc, loại đồ uống gây ngộ độc, thời gian từ khi ngộ độc đến khi vào viện, chẩn đoán và xử trí trước khi vào viện.

- Triếu chứng lâm sàng:

+ Thần kinh: Đau đầu, chóng mặt, hôn mê, co giật, phản xạ gân xương

+ Thị giác: Nhìn mờ, giảm thị lực, mất thị lực, đồng tử giãn, mất phản xạ ánh sáng.

+ Hô hấp: nhip thở, SpO2, suy hô hấp, nhịp thở, ran ở phổi, viêm phổi sặc.

+ Tuần hoàn: mạch, huyết áp, tụt huyết áp

+ Thận, tiết niệu: số lượng nước tiểu: tiểu ít, vô niêu.

+ Các triệu chứng khác: tiêu hóa, tiêu cơ vân, nước tiểu đỏ...

- Cận lâm sàng:

+ Công thức máu, đông máu cơ bản

+ Hóa sinh máu: ure, creatinin, glucose, CK, AST, ALT, bilirubin, điện giải đồ, lactat máu. Nước tiểu: tổng phân tích nước tiểu.

+ Khí máu động mach

+ Áp lực thẩm thấu (ALTT) máu, khoảng trống (KT) ALTT, khoảng trống anion

+ Định lượng methanol và ethanol máu bằng sắc kí khí tai viện Giám định Pháp Y.

+Soi đáy mắt đánh giá tổn thương thị thần kinh, gai thị, võng mạc

+CT hoặc MRI sọ não: đánh giá tổn thương nhân bèo, xuất huyết não, thoái hóa chất trắng, phù não...

- Đánh giá mức độ nặng và suy tạng PSS, APACHE II, SOFA...

- Điều trị: Hồi sức chung: thở oxy, thở máy, truyền dịch, truyền bicarbonat, thuốc vận mạch... 
Điều trị giải độc đặc hiệu (ethanol 20\% đường uống), acid folinic, lọc máu

- Kết quả điều trị: khỏi, di chứng, tử vong.

- So sánh các thông số ở nhóm sống và tử vong để xác định yếu tố liên quan đến tử vong bệnh nhân ngộ độc cấp methanol

Phương tiện nghiên cứu: Các xét nghiệm được làm tại khoa Huyết học, Hóa sinh, Xquang, thăm dò chức nặng của bệnh viện Bạch Mai.

Bệnh nhân điều trị tại Trung tâm Chống độc, sử dụng các máy móc thiết bị của Trung tâm: máy lọc máu, máy thở, chụp xquang tại giường, máy siêu âm, các phương tiện theo dõi, thăm khám và chăm sóc...

2.3. Xử lí số liệu. Số liệu được xử lý theo phương pháp thống kê y học, sử dụng phần mềm SPSS 22.0. So sánh giá trị trung bình bằng t-test student, so sánh tỉ lệ \% bằng test X2 hoặc Fisher Exact test. Phân tích hồi qui tính tỉ số OR và khoảng tin cậy $95 \%$.

\section{KẾT QUẢ NGHIÊN CỨU}

Trong thời gian từ 01/2016-07/2019, có 107 bệnh nhân đủ tiêu chuẩn chọn vào nghiên cứu. Một số kết quả thu được như sau:

\section{1. Đặc điểm chung của bệnh nhân}

3.2. Một số yếu tố liên quan đến tỉ lệ tử vong ở bệnh nhân ngộ độc cấp methanol Bảng 1. Liên quan một số đặc điểm của bệnh nhẩn ngộ độc methanol với tử vong

\begin{tabular}{|c|c|c|c|c|c|}
\hline Chỉ số & $\begin{array}{c}\text { Nhóm sống } \\
(n=63)\end{array}$ & $\begin{array}{c}\text { Nhóm tử vong } \\
(n=44)\end{array}$ & OR & CI95\% & $\mathbf{P}$ \\
\hline Tuổi (năm) & $46,4 \pm 14,68$ & $49,5 \pm 9,91$ & & & $>0,05$ \\
\hline Giới: Nam & $60(95,2 \%)$ & $44(100 \%)$ & \multirow{2}{*}{1466,3} & \multirow{2}{*}{$0,00-0,001$} & \multirow{2}{*}{$>0,05$} \\
\hline Nũ̃ & $3(4,8 \%)$ & 0 & & & \\
\hline $\begin{array}{c}\text { Loại đồ uống } \\
\text { Rượu chứa methanol }\end{array}$ & $50(79,4)$ & $34(77,3 \%)$ & \multirow[t]{2}{*}{1,02} & \multirow[t]{2}{*}{$0,40-2,60$} & \multirow[t]{2}{*}{$>0,05$} \\
\hline Cồn chứa methanol & $13(20,6 \%)$ & $10(22,7 \%)$ & & & \\
\hline Tiền sử nghiện rượu & $50(79,4 \%)$ & $42(95,5 \%)$ & 0,19 & $0,41-0,92$ & $>0,05$ \\
\hline
\end{tabular}

Nhận xét: Tuổi trung bình, giới, tiền sử nghiện rượu, loại đồ uống ở bệnh nhân ngộ độc cấp methanol đều không liên quan tới tử vong $(p>0,05)$.

Bảng 2. Liên quan triệu chứng lâm sàng lúc vào viện với tử vong ở bệnh nhân ngộ độc câp methanol

\begin{tabular}{|c|c|c|c|c|c|}
\hline Chỉ số & $\begin{array}{c}\text { Nhóm sống } \\
(\mathbf{n = 6 3 )}\end{array}$ & $\begin{array}{c}\text { Nhóm tử } \\
\text { vong (n=44) }\end{array}$ & OR & CI95\% & P \\
\hline $\begin{array}{c}\text { Đến viện muộn sau ngộ } \\
\text { độc }>\text { 24giờ }\end{array}$ & $41(65,1 \%)$ & $41(94,2 \%)$ & 1,04 & $1,01-1,06$ & $<0,01$ \\
\hline Suy hô hẫp & $41(65,1 \%)$ & $44(100 \%)$ & 0,042 & $0,005-0,33$ & $<0,05$ \\
\hline Tụt huyêt áp & $2(3,2 \%)$ & $32(72,7 \%)$ & 81,3 & $17,1-385,8$ & $<0,01$ \\
\hline Glasgow < 8 điểm & $24(38,1 \%)$ & $44(100 \%)$ & 0,102 & $0,32-0,331$ & $<0,01$ \\
\hline Co giật & $1(1,6 \%)$ & $6(13,6 \%)$ & 9,78 & $1,13-84,4$ & $<0,05$ \\
\hline Nhìn mờ & $57(90,5 \%)$ & $44(100 \%)$ & 0,09 & $0,04-0,20$ & $>0,05$ \\
\hline Đồng tử giãn & $24(38,1 \%)$ & $42(95,5 \%)$ & 34,1 & $7,56-153,9$ & $<0,01$ \\
\hline Mất phản xạ ánh sáng & $12(19,1 \%)$ & $37(84,1 \%)$ & 22,4 & $8,07-62,5$ & $<0,01$ \\
\hline
\end{tabular}

nghiên cứu

Phân bố theo giới: Bệnh nhân nam là chủ yếu $104 / 107$ BN $(97,2 \%)$; Nữ $3 / 107$ BN (2,8\%). Tỉ lệ bệnh nhân Nam/nữ là 34,7:1

\section{Phân bố theo tuổi:}

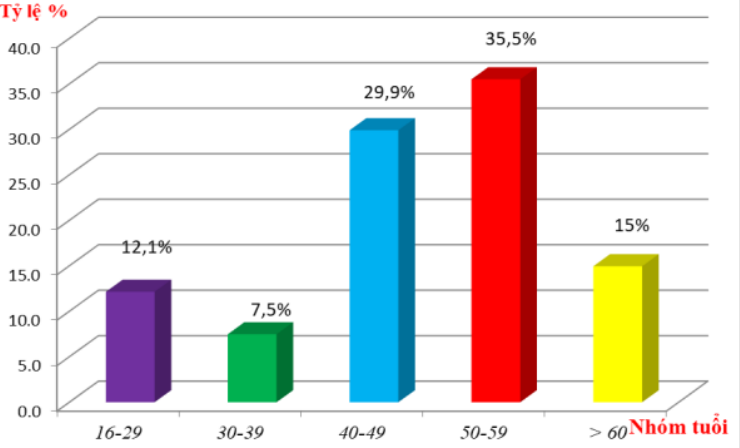

Biểu đồ 3.2: Phân bố BN theo nhóm tuổi

Nhận xét: Tuổi trung bình của BN nghiên cứu là 47,6 $\pm 12,6$ tuổi (16-72). Bệnh nhân chủ yếu ở nhóm tuổi trung niên 40-59 tuổi $(65,4 \%)$, nhóm 50-59 tuổi là 35,5\%, nhóm tuổi khác gặp ít hơn.

- Kết quả điêu trị: Tử vong $44 / 107$ (41,1\%), sống 63/107 BN (58,9\%). 
Nhận xét: Một số dấu hiệu lúc vào viện có liên quan tới tử vong ở bệnh nhân ngộ độc cấp methanol là: vào viện muộn hớn 24 giờ sau khi ngộ độc (OR 1,04; $p<0,01)$, hôn mê sâu (OR 0,102 ; $\mathrm{p}<0,01)$, co giật (OR 9,78; $\mathrm{p}<0,05)$, đồng tử giãn (OR 34,1; $\mathrm{p}<0,01)$, mất phản xạ ánh sáng (OR $22,4 ; p<0,01)$, suy hô hấp (OR 0,042; $p<0,05)$, tụt huyết áp (OR 81,3; $p<0,01)$.

Bảng 3. Liên quan các đặc điểm cận lâm sàng lúc vào viện với tử vong ở bệnh nhân ngộ độc cấp methanol

\begin{tabular}{|c|c|c|c|c|c|}
\hline Chỉ số & $\begin{array}{c}\text { Nhóm sống } \\
(n=63)\end{array}$ & $\begin{array}{c}\text { Nhóm tử } \\
\text { vong }(n=44)\end{array}$ & OR & CI95\% & $\mathbf{P}$ \\
\hline Tăng glucose máu & $39(61,9 \%)$ & $43(97,7 \%)$ & 26,46 & $3,41-104,8$ & $<0,01$ \\
\hline Tiều cơ vân cấp & $4(6,4 \%)$ & $11(25 \%)$ & 4,9 & $1,45-16,67$ & $<0,05$ \\
\hline $\begin{array}{l}\text { Suy thận cấp (creatinin } \\
\text { máu } \geq 130 \mu \mathrm{mol} / \mathrm{l})\end{array}$ & $20(31,8 \%)$ & $38(86,4 \%)$ & 1,02 & $1,002-1,03$ & $<0,05$ \\
\hline pH máu $<7,0$ & $18(28,6 \%)$ & $38(88,6 \%)$ & 0,063 & $0,023-0,175$ & $<0,001$ \\
\hline Tăng lactat máu $>2 \mathrm{mmol} / \mathrm{l}$ & $38(41 \%)$ & $41(93,2 \%)$ & 1,13 & $1,01-1,25$ & $<0,05$ \\
\hline Methanol máu $\geq 50 \mathrm{mg} / \mathrm{dL}$ & $58(82,5 \%)$ & $44(100 \%)$ & 1,007 & $1,001-1,012$ & $<0,05$ \\
\hline Tăng & $57(9$ & 44( & 1, & & $<0,01$ \\
\hline Tăng & $61(\mathrm{c}$ & 4 & 1,01 & $1,($ & $<0,05$ \\
\hline Tăng & $\%)$ & 44 & 11 & 18 & $<0,05$ \\
\hline Tăng bạch c & $46(73,0 \%)$ & $28(63,6 \%)$ & 1,04 & $0,97-1,11$ & $>0,05$ \\
\hline Có tổn thương não & $33(46,5 \%)$ & $12(17,7 \%)$ & 1,08 & $0,79-1,47$ & $>0,05$ \\
\hline Có tổn thương mắt & $29(41,4 \%)$ & $15(21,4 \%)$ & 1,81 & $0,15-22,6$ & $>0,05$ \\
\hline
\end{tabular}

Nhận xét: Một số đặc điểm cận lâm sàng có liên quan tới tử vong ở bệnh nhân ngộ độc cấp methanol là: tăng glucose máu $(O R 26,46 ; p<0,01)$, tiêu cơ vân cấp $(O R 4,9 ; p<0,05)$, suy thận cấp (OR 1,02; $p<0,05)$, toan máu nặng (OR 0,$063 ; p<0,001)$, tăng lactat máu $(O R 1,13 ; p<0,05)$, tăng ALTT máu (OR 1,02; $p<0,01)$, tăng KTALTT máu (OR 1,$01 ; p<0,05)$, tăng KT anion (OR 1,11 ; $\mathrm{p}<0,05)$, nồng độ methanol máu $>50 \mathrm{mg} / \mathrm{dl}(\mathrm{p}<0,05)$.

Bảng 4. Liên quan giữa các biện pháp điều trị với tử vong ở bệnh nhân ngộ độc methanol

\begin{tabular}{|c|c|c|c|c|c|}
\hline Chỉ số & $\begin{array}{c}\text { Nhóm sống } \\
(\mathbf{n = 6 3 )}\end{array}$ & $\begin{array}{c}\text { Nhóm tữ } \\
\text { vong (n=44) }\end{array}$ & OR & CI95\% & p \\
\hline Phải dùng thuốc vận mạch & $7(11,1 \%)$ & $40(90,9 \%)$ & 0,13 & $0,003-0,046$ & $<0,001$ \\
\hline Phải thở máy & $40(63,5 \%)$ & $44(100 \%)$ & 0,00 & $0,00-0,00$ & $>0,05$ \\
\hline Dùng ethanol 20\% đường uống & $50(79,4 \%)$ & $38(86,4 \%)$ & 1,64 & $0,57-4,73$ & $>0,05$ \\
\hline Dùng folinic acid & $14(22,2 \%)$ & $24(54,5 \%)$ & 1,23 & $0,64-4,79$ & $>0,05$ \\
\hline Dùng bicarbonat & $58(92,1 \%)$ & $44(100 \%)$ & 0,00 & $0,00-0,00$ & $>0,05$ \\
\hline $\begin{array}{c}\text { Lượng bicarbonat cần dùng } \\
>\text { >500mEq }\end{array}$ & $17(27,0 \%)$ & $2761,4 \%)$ & 4,29 & $1,88-9,78$ & $<0,05$ \\
\hline
\end{tabular}

Nhận xét: Bệnh nhân phải dùng thuốc vận *Giá trị tiên lượng tử vong của các triệu mạch, lượng bicarbonat cần dùng cao $>500 \mathrm{mEq}$ có mối liển quan với tỉ lệ tử vong. BN phải dùng thuốc vận mạch: OR: 0,13; (CI95\%: 0,003$0,046) ; p<0,001$; và cần truyền bicarbonat $>$ 500mEq là: OR 1,002; (CI95\%: 1,001- 1,004); $\mathrm{p}<0,05$. chứng lâm sàng, cận lâm sàng, biện pháp điều trị với tử vong ở bệnh nhân ngộ độc methanol. Từ kết quả phân tích đơn biến, những yếu tố có sự liên quan có ý nghĩa $(p<0,05)$ được phân tích hồi quy đa biến logistic để tìm ra các yếu tố có giá trị tiên lượng độc lập với tử vong, kết quả như sau:

Bảng 3.5. Giá trị tiên lượng tử vong của các triệu chứng lâm sàng, cận lâm sàng, biện pháp điều trị ở bệnh nhân ngộ độc methanol

\begin{tabular}{|c|c|c|c|}
\hline Chỉ số & OR & CI 95\% & p \\
\hline Đến viện muộn sau ngộ độc > 24giờ & 1,04 & $1,00-1,08$ & $<0,05$ \\
\hline Hôn mê sâu (Glasgow < 8 điểm) & 2,40 & $1,10-4,80$ & $<0,05$ \\
\hline Suy hô hấp & 0,05 & $0,001-3,26$ & $>0,05$ \\
\hline Co giật & 5,67 & $0,51-62,38$ & $>0,05$ \\
\hline Đồng tữ giãn & 1,02 & $0,45-23,33$ & $>0,05$ \\
\hline
\end{tabular}




\begin{tabular}{|c|c|c|c|}
\hline Mất phản xạ ánh sáng & 2,91 & $0,62-13,65$ & $>0,05$ \\
\hline Glucose tăng & 13,28 & $1,45-121,5$ & $<0,05$ \\
\hline Tiêu cơ vân cấp & 2,9 & $0,58-14,56$ & $>0,05$ \\
\hline Suy thâ̂n cấp & 5,13 & $1,60-16,40$ & $<0,05$ \\
\hline pH máu $<7,0$ & 2,20 & $1,15-9,70$ & $<0,05$ \\
\hline Tăng lactat máu $(>2 \mathrm{mmol} / \mathrm{l})$ & 1,59 & $0,22-11,65$ & $>0,05$ \\
\hline Nồng độ methanol $\geq 50 \mathrm{mg} / \mathrm{dL}$ & 1,05 & $0,98-1,01$ & $>0,05$ \\
\hline Tăng áp lực thẩm thấu máu & 1,01 & $0,99-1,01$ & $>0,05$ \\
\hline Tăng khoảng trống áp lực thấm thấu & 1,01 & $1,00-1,03$ & $>0,05$ \\
\hline Tăng khoảng trống anion & 1,03 & $0,94-1,14$ & $>0,05$ \\
\hline Tụt huyết áp phải dùng thuốc vận mạch & 3,90 & $1,04-10,50$ & $<0,01$ \\
\hline Lượng bicarbonat cần dùng >500mEq & 1,04 & $0,24-5,08$ & $>0,05$ \\
\hline
\end{tabular}

Nhận xét: Một sỗ các yễu tố liên quan và có giá trị tiên lượng tử vong ở bệnh nhân ngộ độc cấp methanol là:

Đến viện muộn sau ngộ độc quá 2giờ: $O R$ 1,04; (CI95\%: 1,0-1,08); $p<0,05$.

Hôn mê sâu: (glasgow < 8 điểm) OR 2,40; (CI95\%: 1,1- 4,80); $\mathrm{p}<0,05$

Toan chuyển hóa nặng: $\mathrm{pH}<7,0$; OR 2,2; (CI95\%: 1,15- 9,7); $p<0,05$.

Suy thận cấp: OR 5,13; (CI95\%: 1,6-16,4); $\mathrm{p}<0,05$.

Tăng glucose máu: OR 13,28;(CI95\%: 1,45$121,5) ; p<0,05$.

Tụt huyết áp phải dùng thuốc vận mạch: OR: 3,9; (CI95\%:1,04- 10,5); $p<0,01$.

\section{BÀN LUÂ̂N}

4.1. Đặc điểm chung của bệnh nhân nghiên cứu

Phân bố về giới tính: Trong nghiên cứu, chúng tôi gặp chủ yếu là bênh nhân nam $104 / 107 \mathrm{BN}(97,2 \%)$ và chỉ có $3 / 107 \mathrm{BN}$ nữ $(2,8 \%)$. Thực tế ở Việt Nam, nam hay uống rượu nhiêu hơn nữ, nghiện rượu thường chỉ gặp ở nam giới. Chính vì vậy, khi uống rượu và cồn chứa methanol gây ngộ độc cũng sẽ gặp chủ yếu ở bệnh nhân nam. Nhận xét của chúng tôi cũng tương tự nghiên cứu của các tác giả: của Nguyễn Đàm Chính, nam giới chiếm 90\% [1], của Phạm Như Quỳnh nam giới là 96,67\% [2], của Lee Chen-Yen nam giới 87,5\% [7].

Một số nghiên cứu của nước ngoài có phân bố giới khác vì tỉ lệ nữ giới ở nước ngoài uống rượu nhiều hơn ở Việt nam.

- Phân bố về tuổi: tuổi trung bình của các bênh nhân là 47,6 \pm 12,6 tuổi, nhóm tuổi trung niên 40-59 tuổi chiếm tî lệ cao $(65,4 \%)$. Kết quả của chúng tôi tương tự nghiên cứu của Phạm Như Quỳnh năm 2017, nhóm tuổi 50-59 chiếm 29,73\% [2]; nghiên cứu Lee C.Y. năm 2014 là $46,1 \pm 13,8$ tuổi [7].
Kêt quả điều trị: Tỉ lệ tử vong trong nghiên cứu của chúng tôi là $44 / 107(41,1 \%)$, sống 63/107 BN (58,9\%). Ngộ độc methanol là cấp cứu nặng, tî lệ tử vong cao vì các biến chứng nă̆ng và các bệnh nhân thường tới muộn. Khi bệnh nhân uống rượu có cả methanol và ethanol, vì có chung enzym chuyển hóa nhưng enzym lại có ái lực với ethanol gấp gần 10 lần so với methanol nên lúc đầu sẽ chuyển hóa ethanol trước, methanol được chuyển hóa chậm hơn nên các triêuu chứng cũng xuất hiện muộn hơn.

\subsection{Mối liên quan của triêu chứng lâm} sàng, cận lâm sàng khi vào viện và điều trị với tử vong của bệnh nhẩn ngộ độc methanol. Khi phân tích đơn biến các yếu tố lâm sàng, cận lâm sàng lúc vào viện, chúng tôi thây nhiêuu yếu tố có liên quan tới tới tử vong ở bệnh nhân ngộ độc cấp methanol. Các yếu tố lâm sàng là vào viện muộn hơn 24 giờ sau khi ngộ độc, hôn mê sâu, co giật, đồng tử giãn, mất phản xạ ánh sáng, suy hô hấp, tụt huyết áp. Các dấu hiệu cận lâm sàng là: tăng glucose máu, tiêu cơ vân cấp, suy thận cấp, toan máu nặng, tăng lactat, tăng áp lực thẩm thấu, khoảng trống thẩm thấu, tăng khoảng trống anion máu và nồng độ methanol máu > 50mg/dl. Liên quan với các biện pháp điều trị thì có bệnh nhân phải dùng thuốc vận mạch, phải dùng lượng bicarbonat cao $>500 \mathrm{mEq}$ thì nguy cơ tử vong cao hơn.

Tuy nhiên khi phân tích đa biến chúng tôi thấy các yếu tố có giá trị tiên lượng tử vong là: thời gian đến viện muộn sau ngộ độc quá $24 \mathrm{~h}$, hôn mê sâu, toan chuyển hóa nặng, suy thận cấp, tăng glucose máu, tụt huyết áp phải dùng thuốc vận mach.

Nhiều nghiên cứu của các tác giả trên thế giới đã đưa ra các kết quả khá tương đồng, tùy theo nhóm đối tượng nghiên cứu:

Nghiên cứu của Hassanian-Moghaddam tai bệnh viện Loghman-Hakim của Iran trên 25 bệnh nhân ngộ độc methanol. Tử vong 12BN 
(48\%), tác giả nhận thấy thời gian từ khi ngộ độc đến khi vào viện trên 24 giờ, bệnh nhân bị hổn mê, pH máu $<7,0$ là các yếu tố tiên lượng tử vong ở bệnh nhân ngộ độc methanol [5].

Nghiên cứu của Lee Chen-Yen tại Đài Loan trên 32BN ngộ độc methanol, tác giả thây các yếu tố liên quan tới tử vong là: Hôn mê sâu (OR 0,816; CI95\%: 0,682-0,976; $p=0,026)$; Tăng creatinin (OR 4,79; CI95\%: 1,32-17,44; $p=0,017)$; Hạ thân nhiệt $(p=0,015)$. Tuy nhiên, tác giả Lee Chen-Yen không nhận thấy $\mathrm{pH}$ là yếu tố có ý nghĩa tiên lượng tử vong (OR 0,247; CI95\%:0,004-17,212; $p=0,519$ ) [8].

Hovda KE và cộng sự nghiên cứu 51 BN ngộ độc methanol tại Na Uy, tử vong $18 \%$. Các tác cho rằng ngộ độc cấp methanol tử vong cao chủ yếu do chẩn đoán và điều trị muộn, các yếu tố như suy hô hấp, hôn mê, nhiễm toan chuyển hóa nặng $(\mathrm{pH}<6,9)$ là yếu tố tiên lượng tử vong [6].

Nghiên cứu của Sanaei -Zadeh và cộng sự trên 95 BN trong vòng 8 năm (2003-2010). Các tác giả đưa ra nhận định: tăng đường máu có ý nghĩa tiên lượng tử vong trong ngộ độc methanol (OR 6,5; CI95\%:1,59-26,4); $p<0,01$ ), giá trị cut off của glucose máu là $140 \mathrm{mg} / \mathrm{dL}$. Ngoài tăng đường máu, còn có toan máu pH (OR $-0,242 ; p=0,02)$; nồng độ bicarbonat (OR 0,23; $\mathrm{p}=0,03)[9]$

Tác giả Coulter C.V và cộng sự nghiên cứu tại New Zealand trên 119 BN, trong đó có 31BN ngộ độc methanol, tử vong do methanol là 20BN. Tác giả kết luận: tăng áp lực thẩm thấu máu, tăng khoảng trống anion, pH máu $<7,22$ là các yếu tố liên quan tới tử vong. Trong các yếu tố liên quan, $\mathrm{pH}<7,22$ có giá trị tiên đoán cao nhất, AUC 0,94 (CI95\%: 0,89-0,99; p < 0,001) [4]

Một nghiên cứu đa trung tâm, đa quốc gia của Paasma $R$ và các cộng sự, kết quả được công bố trên Clin Toxicol (Phila) năm 2012. Nghiên cứu trên có 203 BN ngô độc methanol, tử vong 48BN (23,65\%). Các dấu hiệu như: hôn mê sâu (Glasgow $<8$ điểm), toan chuyển hóa (pH máu <7) là các yếu tố tiên lượng tử vong ở bệnh nhân ngộ độc methanol [8].

Nghiên cứu mới nhất được công bố gần đây trên BMC Nephrology (2019) của Chang Shu Ting và cộng sự ở Taiwan, nghiên cứu trên 50 BN ngộ độc methanol tại bệnh viện Chang Gung. Kết quả cho thấy tổn thương thận cấp ( $O R$ 19,76; CI95\% 1,026-337,008; $p=0,048$ ) và hôn mê (glasgow) là yếu tố tiên lượng tử vong ở BN ngộ độc methanol [3]

\section{KẾT LUẬN}

Bệnh nhân chủ yếu là nam giới $(97,2 \%)$; tuổi trung bình là $47,6 \pm 12,6$ năm và nhóm tuổi 40-59 gặp nhiều nhất $(65,4 \%)$.

- Ngộ độc methanol thường nặng, tỉ lệ tử vong cao $(41,1 \%)$.

- Một số yếu tố liên quan đến tử vong ở bệnh nhân ngộ độc cấp methanol:

+ Đến viện muộn sau ngộ độc quá 24 giờ (OR

$1,04 ; p<0,05)$.

+ Hôn mê sâu (OR 2,4; $p<0,05)$

+ Toan chuyển hóa nặng $\mathrm{pH}<7,0$ (OR 2,2;

$p<0,05)$.

+ Suy thận cấp (OR 5,13; $p<0,05)$.

+ Tăng glucose máu (OR 13,28; $p<0,05)$.

+ Tụt huyết áp phải dùng thuốc vận mạch (OR 3,9; $p<0,01$ ).

\section{TÀI LIÊU THAM KHẢO}

1. Nguyễn Đàm Chính (2013). Đặc điểm lâm sàng, cận lâm sàng ngô đồc cấp Methanol. Luận văn thạc sĩ, Đại học Y Hà Nội 2013.

2. Pham Như Qừ̀nh, Lê Đình Tùng, Hà Trân Hưng (2017). Hiệu quả của thẩm tách máu kéo dài trong điều trị bệnh nhân ngộ độc cấp methanol. Tạp chí Sinh lý học Việt Nam, 21(3), 13-20.

3. Chang S.T., Wang Y.T., Hou Y.C., et al (2019). Acute kidney injury and the risk of mortality in patients with methanol intoxication. BMC Nephrol 20: 205.

4. Coulter C.V., Farquhar S.E., McSherry C.M., et al (2011). Methanol and ethylene glycol acute poisonings - predictors of mortality. Clin Toxicol (Phila); 49(10): 900-6.

5. Hassanian-Moghaddam A Dadgar S.M. et al (2007) Pajoumand factors in methanol poisoning. Human \& Experimental Toxicology, 26: 583-586.

6. Hovda K.E.., Hunderi O.H., Tafjord A..B, et al (2005). Methanol outbreak in Norway 2002-2004: epidemiology, clinical features and prognostic signs. J Intern Med, 258(2), 181-90.

7. Lee C.Y., Chang L.K., Lin J.L, et al (2014). Risk factors for mortality in Asian Taiwanese patients with methanol poisoning. Ther Clin Risk Manag, 10, 61-7.

8. Paasma R., Hovda K.E., HassanianMoghaddam $H_{\text {., }}$ et al (2012). Risk factors related to poor outcome after methanol poisoning and the relation between outcome and antidotes a multicenter study. Informa Healthcare USA, Inc, Clinical Toxicology, 50, 823-831.

9. Sanaei-Zadeh H., Esfeh S.K., Zamani N., et al (2011). Hyperglycemia is a strong prognostic factor of lethality in methanol poisoning. J Med Toxicol, 7(3), 189-94. 